\title{
Actors, Motivations and Outcomes in the Legislative Process: Policy Influence at Westminster ${ }^{1}$
}

\author{
Meg Russell, Daniel Gover, Kristina Wollter, Meghan Benton \\ Corresponding author: meg.russell@ucl.ac.uk
}

Accepted for publication in Government and Opposition

\begin{abstract}
Legislatures in parliamentary systems are frequently seen as weak policy actors, and this is nowhere more true than of the British Westminster parliament. But real-world changes, and recent research, suggest that Westminster's influence is significant and growing. This raises new questions about which non-government actors are influential, which we explore through analysing 4361 amendments proposed to 12 government bills. But assessing non-government amendment 'success' presents challenges, since many such proposals are clearly not sincere attempts at legislative change. We thus make two substantive contributions. First, we quantitatively assess the influence of different groups at Westminster, showing both non-government influence and cross-party working to be more extensive than traditionally assumed. Second, we link predictions about opposition and backbench parliamentarians' motivations to the legislative amendment process, proposing a typology of motivations for such amendments, with wider application. Overall, we argue that understanding non-government parliamentarians' diverse motivations shows that they 'fail' far less than commonly assumed.
\end{abstract}

\section{Introduction}

Legislatures in parliamentary systems are often seen as relatively weak. Bills need formal parliamentary approval to become law, but cohesive parties and the confidence relationship between government and legislature can create the impression of executive dominance. Thus scholars often note how most government-initiated bills and amendments are agreed, while most proposals from non-government actors fail (e.g. Arter 1985, Kerrouche 2006, Zubek 2011). The Westminster majoritarian system is often presented as an extreme case of such dynamics, contrasted with greater assumed legislative influence in multi-party or presidential systems (e.g. Kreppel 2014, Lijphart 2012, Martin and Vanberg 2011).

Yet recent UK developments, and new research approaches, have challenged such assumptions - showing Westminster to have substantial hidden influence of what Blondel (1970: 78, 82) termed both 'reactive' and 'preventive' kinds. This raises questions about which groups of non-government parliamentarians at Westminster have influence, and why. Our paper addresses such questions, by analysing 4361 amendments proposed to 12 government bills during their UK parliamentary passage. But studying non-government amendment success provokes further questions about actors' motivations for proposing such amendments - since many are found not actually to be sincere attempts at legislative change. As well as assessing policy influence at Westminster we thus offer a tentative typology of motivations for legislative amendments with wider potential application. 
The remainder of the article is structured in seven parts. We first present some background on legislative decision-making as presently understood, and set out our research questions. We then summarise our methods. Next we present initial quantitative data on the success of nongovernment amendments at Westminster. This is followed by three sections, in turn, on the role of opposition frontbenchers, government backbenchers, and cross-party groups, drawing on both qualitative and quantitative evidence. Finally we present our conclusions. These indicate that cross-party work and opposition policy proposals are both more important at Westminster than generally assumed, challenging common assumptions in both British and comparative politics. But we also argue that non-government amendment 'failure' should not be taken at face value, and that better understanding of the multiple motivations behind legislative amendments - as well as of 'preventive' influence - is necessary for the better understanding of legislatures.

\section{Parliaments, actors and outcomes}

In both comparative studies (e.g. Martin and Vanberg 2011, Mezey 1979) and accounts of domestic politics (summarised in Flinders and Kelso 2011) the UK parliament is typically presented as weak. While similar claims are made in many other parliamentary systems, the 'Westminster model' is particularly closely associated with legislative weakness and excessive executive control (Lijphart 2012).

But recent changes at Westminster have been significant. In the Commons, the departmental 'select committees' have grown in strength and reputation (Benton and Russell 2012, Kelso 2009), while party voting cohesion has gradually declined (Cowley 2002, 2005, Cowley and Stuart 2012). In the Lords, a reform in 1999 that removed most hereditary peers and created a 'no overall control' chamber gave members both greater confidence, and greater potential, to challenge government policy (Russell 2010, 2013). The failure of any party to gain an overall Commons majority in 2010 then brought Britain closer to the European norm, producing its first post-war coalition government.

Scholars studying Westminster have thus begun making more sophisticated uses of data to chart clear evidence of influence (e.g. Benton and Russell 2012, Cowley 2002, 2005, Russell 2013, Russell and Sciara 2008, Thompson 2013). We recently added to this, with a detailed study of 12 government bills 2005-12, proposing six 'reasons for doubt' regarding executive dominance at Westminster (reference withheld). Ours was the most detailed research on the British legislative process since the major study by Griffith (1974) over 40 years ago, and we believe is unrivalled in recent study of other domestic parliaments. Tracking 4361 legislative amendments, we demonstrated that while almost all agreed amendments were proposed by ministers, $69 \%$ of government amendments had little policy substance, while $60 \%$ of those with substance followed pressure from non-government parliamentarians. Too literal a reading of amendment outcomes thus risks overstating both government success and nongovernment failure. It also overlooks parliament's significant influence before and after the formal legislative process.

But if there is, as various scholars claim, 'increasing influence' at Westminster (Ryle 2005: 11) this raises questions about which group(s) in parliament the government listens to, and why. These questions were addressed by Anthony King's (1976) now classic analysis, which is also four decades old. King compared 'modes of executive-legislative relations' in Britain, France and Germany, suggesting that the 'opposition mode' was 'the one in which the larger part of party politics in Britain [took] place'. Yet there was little expectation that such 
confrontations had policy effect, as in a majoritarian setting the 'Government fully expect the Opposition to make hostile speeches. It does not need, or want, the Opposition's moral support... [or] votes' (King 1976: 17-18). More recent analyses conform to this assumption, presenting oppositions in majoritarian settings as essentially office- rather than policyseeking, with 'the UK model... a standout case of negative rather than constructive oppositional politics' (Andeweg 2013, Helms 2004, 2008, Kaiser 2008, Norton 2008, Uhr 2009: 67). Such authors assume that policy-seeking opposition is more prevalent in 'consensus' style democracies, though a recent study of legislative amendments in two such parliaments failed to bear this out (Martin and Vanberg 2005).

Turning to other 'modes' at Westminster, King emphasised that when the governing party has a Commons majority, and the Lords is weak, the key swing voters are its own backbench MPs. The primary dynamic in terms of influence was thus the 'intraparty mode'. In contrast the 'inter-party mode', key to coalition politics in Germany, and also visible in France, clearly did not apply. The 'cross-party mode' - also important in Germany thanks to specialist committees (and the Bundesrat, though King did not consider intercameral aspects) - was likewise judged so weak as to be non-existent. But subsequent changes at Westminster may well have changed these dynamics.

Our previous article (reference withheld) did not explore the relative success rates of amendments from different kinds of non-government parliamentarians. Griffith's (1974) prior study found that more opposition amendments than government backbench amendments went on to be taken up but that the overall success rate of opposition amendments was low because they were so numerous. Nonetheless our findings emphasised that the apparent 'failure rate' of non-government amendments was misleading - partly because some of these lead to ministerial proposals, but also because non-government parliamentarians freely admit that their amendments are often not sincere attempts at legislative change. This is consistent with the acknowledged diverse motivations of opposition parties (see above), and also studies of the interparty politics of coalition (e.g. Martin and Vanberg 2008). Scholars conducting other amendment analyses have likewise noted that '[a]mendments may have one or more of a great variety of purposes' (Griffith 1974: 37). Hence Shephard and Cairney (2005: 307) observed that proposers of amendments in the Scottish Parliament may have 'masked motives' of 'numerous' kinds; while Judge and Earnshaw (2003: 102) acknowledged the difficulty of measuring influence in the European Parliament, given the 'propagandistic' nature of some amendments. But to date, while the diversity of motivations for amendments has been noted, no systematic typology has been proposed.

So we are now left with several questions. The first concerns influence in British politics, in terms of which actors at Westminster achieve changes to legislation and why. Echoing King (1976), we first focus on the separate contributions of the opposition frontbench and government backbenchers. We then consider cross-party working, to explore whether recent changes have indeed strengthened this 'mode', bringing Westminster more into line with other European legislatures. Our assessment considers both visible 'reactive' influence, through amendments, and less visible 'preventive' influence (Blondel 1970), through government seeking to anticipate legislative concerns. Second, given how central Westminster is to the wider literature, we ask how these findings can inform study about parliamentary actors' strategies more generally, both in majoritarian and consensus settings. In particular, we explicitly link the literature on such strategies to that on legislative amendments, to develop a typology of motivations for proposing such amendments, mapped onto different groups. We argue that the influence of legislative institutions will always be 
understated, and perhaps underappreciated, unless the diversity of motivations for nongovernment amendments is better understood.

\section{Methods and data}

Our analysis uses 12 government bills at Westminster: seven in the 2005-10 parliament (when Labour was in government), and five from 2010-12 (under the Conservative/Liberal Democrat coalition). ${ }^{2}$ Although such a small sample can never be completely representative, the bills were selected on a range of indicators - for example coming from different government departments, having varying length and levels of controversy, and starting their parliamentary passage in Commons or Lords.

Our starting point is all 4361 amendments proposed during these bills' passage through both chambers of parliament - as summarised in Table 1. As seen, there are seven stages when amendments may potentially be agreed - three in the Commons, and four in the Lords including the stages when each chamber considers the other's amendments, which may occur repeatedly. When disputes arise the Commons can as a last resort override the Lords, but most disagreements are instead resolved through negotiation (Russell 2013).

Table 1: Amendments proposed to 12 case study bills, by legislative stage and outcome

\begin{tabular}{|l|r|r|r|r|}
\hline Legislative stage & Agreed & Disagreed & $\begin{array}{r}\text { Withdrawn, } \\
\text { etc }\end{array}$ & Total \\
\hline Commons committee & 160 & 65 & 975 & 1200 \\
\hline Commons report & 144 & 29 & 406 & 579 \\
\hline Lords committee & 116 & 7 & 1373 & 1496 \\
\hline Lords report & 331 & 20 & 458 & 809 \\
\hline Lords third reading & 51 & 5 & 23 & 79 \\
\hline Commons consideration of Lords amendments & 96 & 1 & 13 & 110 \\
\hline Lords consideration of Commons amendments & 66 & 8 & 14 & 88 \\
\hline Total & 964 & 135 & 3262 & 4361 \\
\hline As \% of total & $22 \%$ & $3 \%$ & $75 \%$ & $100 \%$ \\
\hline
\end{tabular}

In terms of outcomes, almost a thousand amendments were agreed, and only 135 rejected, with or without a division (i.e. recorded vote). But three-quarters were not formally decided on at all - for example because they were not selected, not moved, or withdrawn. ${ }^{3}$

Nonetheless many of these amendments were debated, and some went on to be influential, as further discussed below.

We coded all of these amendments on a range of key variables. Some - e.g. the party (or parties) of the parliamentarian(s) proposing the amendment - were objective and straightforward. Others - e.g. the amendment's policy substantiveness, or proposed legislative effect - were less so. But we used a detailed coding scheme, and each researcher's codes were checked by another. The building of our dataset drew on, but also went significantly beyond, the methods used in previous amendment analyses (e.g. Griffith 1974, Kreppel 1999, Shephard and Cairney 2005) - in particular to deal with the lengthy nature of the Westminster legislative process. By coding the proposers of individual amendments, and 
including both those that succeeded and those that failed, we also went beyond ascribing influence solely on the basis of actual change and known party positions (e.g. Martin and Vanberg 2005).

We traced influence by linking each amendment to any others with similar effect proposed at earlier or later stages, in what we called legislative 'strands'. The shortest strands involved relatively unique amendments, occurring at just one legislative stage, while the longest comprised 13 such stages. At any one stage, a strand could include only one legislative proposal (i.e. a lead amendment and any associated consequential amendments) proposed by one actor/group - unless one of the actors was government. ${ }^{4}$ This reduced the 4361 amendments to 2050 distinct legislative strands. Of these, 300 could easily be judged 'successful', because they included at least one amendment (usually from a minister) which was agreed and not subsequently overturned. An additional 176 strands also contributed to policy changes, usually because a successful amendment was made in a related strand. ${ }^{5}$ Hence 476 strands in total were judged 'not unsuccessful'. The remaining 1574 were wholly unsuccessful, resulting in no policy change.

Construction of strands allowed us to chart otherwise hidden influence. Because government amendments were grouped with any related non-government proposals, the policy effects of these could be seen. Typically non-government amendments are withdrawn (sometimes at one stage, sometimes repeatedly), following ministerial promises to reflect, or to bring forward revised proposals. ${ }^{6}$ Importantly, the method also allowed us to trace which groups' proposals ultimately attained success. Plus it avoided ascribing spurious influence to nongovernment amendments that passed, but were later overturned.

In addition to coding amendments and strands, we conducted over 120 interviews with policy actors closely involved with the case study bills. These included front and backbenchers in both chambers from government and non-government parties, civil servants, parliamentary officials and representatives of outside lobby groups. The interviews helped validate our quantitative analysis, but primarily helped uncover behind-the-scenes negotiations, and explore actors' motivations and strategies.

\section{Measuring legislative influence through amendment success}

The crudest use of this data would be to look at the success rates of government and nongovernment amendments. Of our 4361 amendments, 886 were proposed in the name of a minister, and 839 (95\%) of these were agreed. ${ }^{7}$ The remaining 3475 came from nongovernment actors (i.e. backbenchers, opposition frontbenchers or non-party parliamentarians) - of these just 125 were agreed $^{8}$, of which 99 were overturned later in the process (a visible success rate of below $0.01 \%$ ). Yet, as indicated above, our analysis demonstrated that just a third of government amendments had policy substance, and a majority of these responded to points raised by non-government parliamentarians (reference withheld). ${ }^{9}$ As Table 2 shows, legislative strands allow us to explore who these nongovernment actors were. Because of the change of party positions in 2010, figures are shown separately for 2005-10 and 2010-12. 
Table 2: Outcome of strands by group(s) sponsoring initial amendment(s)

\begin{tabular}{|c|c|c|c|c|c|c|c|c|}
\hline & \multicolumn{4}{|c|}{$2005-10$} & \multicolumn{4}{|c|}{$2010-12$} \\
\hline & 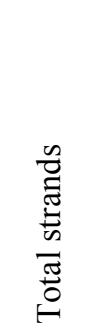 & 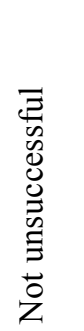 & 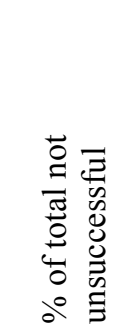 & 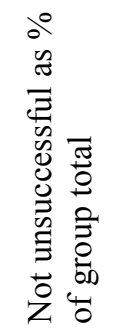 & 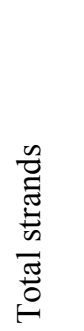 & 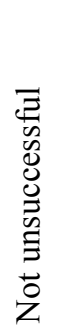 & 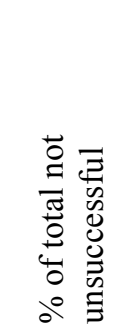 & 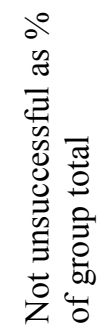 \\
\hline Government frontbench & 102 & 101 & $48.6 \%$ & $99.0 \%$ & 84 & 81 & $30.2 \%$ & $96.4 \%$ \\
\hline Labour frontbench & - & - & - & - & 368 & 68 & $25.3 \%$ & $18.5 \%$ \\
\hline Conservative frontbench & 502 & 41 & $19.7 \%$ & $8.2 \%$ & - & - & - & - \\
\hline LibDem frontbench & 246 & 30 & $14.4 \%$ & $12.2 \%$ & - & - & - & - \\
\hline Joint Con/LibDem frontbench & 72 & 8 & $3.8 \%$ & $11.1 \%$ & - & - & - & - \\
\hline Labour backbench & 80 & 10 & $4.8 \%$ & $12.5 \%$ & 183 & 40 & $14.9 \%$ & $21.9 \%$ \\
\hline Conservative backbench & 75 & 5 & $2.4 \%$ & $6.7 \%$ & 22 & 5 & $1.9 \%$ & $22.7 \%$ \\
\hline LibDem backbench & 8 & 1 & $0.5 \%$ & $12.5 \%$ & 84 & 30 & $11.2 \%$ & $35.7 \%$ \\
\hline Crossbench & 11 & 1 & $0.5 \%$ & $9.1 \%$ & 31 & 6 & $2.2 \%$ & $19.4 \%$ \\
\hline Other (none of the above) & 4 & 0 & $0.0 \%$ & $0.0 \%$ & 4 & 0 & $0.0 \%$ & $0.0 \%$ \\
\hline Other mixed groups & 61 & 11 & $5.3 \%$ & $18.0 \%$ & 113 & 38 & $14.2 \%$ & $33.6 \%$ \\
\hline Total & 1161 & 208 & $100.0 \%$ & $17.9 \%$ & 889 & 268 & $100.0 \%$ & $30.1 \%$ \\
\hline
\end{tabular}

During 2005-10, 208 legislative strands helped initiate policy change. ${ }^{10}$ Just under half of these originated with the government, but the majority (107) began with non-government amendments. The two opposition parties - individually or jointly - initiated by far the largest number of strands -820 . Of these, $79(9.6 \%)$ ended in some kind of policy success. In contrast, government backbenchers initiated only 80 strands, of which just 10 (12.5\%) resulted in policy change. Thus, opposition-initiated strands succeeded more frequently, but in terms of the proportion of each group's amendments government backbenchers may have been marginally more successful. However a chi-squared test shows no statistically significant difference between the two.

In 2010-12 the pattern was similar, with hundreds of strands initiated by the main opposition party (Labour), and just over 100 by government backbenchers. The proportion of nongovernment-initiated strands resulting in change was markedly higher than for 2005-10, though this was somewhat skewed by events on one particular bill. ${ }^{11}$ Again, the largest number of non-government-initiated strands resulting in change came from opposition frontbenchers, but the success rate of government backbenchers - particularly Liberal Democrats - appeared somewhat higher (33.0 to 18.5\%). A chi-squared test does indicate statistical significance $(\mathrm{p}<0.01)$, but the numbers are small.

The numeric data thus do little to suggest that government backbenchers are Westminster's most influential non-ministerial actors. The greater overall number of successful legislative initiatives come from the opposition. This group makes a particularly large numbers of proposals - but its success rate is relatively poor. To gain a fuller understanding of this data, more qualitative exploration is needed, which we turn to next. Ministers almost invariably 
move amendments only when they actually wish to see change to a bill, and can generally rely on their Commons majority to achieve this. In contrast, non-government parliamentarians, having less ability to garner a majority in the division lobbies, may propose amendments for various other reasons.

\section{Opposition frontbench}

We start with the opposition frontbench, which is responsible for by far the largest number of both amendments and legislative strands. Across the 12 bills, 1116 strands (and 2028 amendments) originated with frontbenchers in one or other of the main opposition parties. ${ }^{12}$ Yet almost $90 \%$ of these proposals had no discernible legislative effect.

Given that scholars often divide opposition strategies into office-seeking in majoritarian democracies such as Britain, and policy-seeking in more consensus settings (Helms 2004), this lack of visible influence is hardly surprising. Scholars classically suggest that for opposition politicians Westminster serves as 'merely a forum from which to influence the next election... not an arena to influence public policy' (Andeweg 2013: 102), primarily providing a forum for the opposition to present itself as a credible alternative government. As the UK's longest-serving opposition leader of the 20th century, Neil Kinnock, has put it, 'the only test of a good opposition is to stop being in opposition' (2011: 131). This group's real focus is thus traditionally longer-term electoral success, not short-term policy impact.

In this respect it could be seen as odd for opposition parties to propose so many legislative amendments - implying that these are driven by other motivations, beyond actual legislative change. Opposition interviewees freely admitted this to us. Interviews suggested four additional broad categories of motivation, which we call information seeking, policy signalling, political gameplaying and procedural devices.

Information seeking. It is widely noted that the role of 'Her Majesty's Loyal Opposition' is particularly well-established and institutionalised in the British system, giving the main opposition party a clear function in exposing government policies to scrutiny (Helms 2004, Johnson 1997, Norton 2008). It - and to some extent the smaller opposition parties - is formally recognised through 'opposition days' for debate, privileges during question times and other debates, and informally through frequent selection of its Commons amendments. ${ }^{13}$ Hence the main opposition party has significant agenda-setting power, in return for which its frontbenchers take the lead in subjecting bills to scrutiny. And at Westminster legislative debate is structured primarily around amendments. These form the main tool for extracting information about the government's policy intent, resulting in large numbers of so-called 'probing' amendments, particularly at the committee stage (where the main clause-by-clause scrutiny occurs). In total there were 1485 opposition frontbench amendments at this stage. Frontbenchers freely admit that they, for example, 'just wanted to have a brief debate to understand what [the government] were going to do' using amendments 'never intended to appear on the face of the bill', and which would even 'make the bill make no sense'. This process hence enables parliamentarians to test policy robustness, and identify possible flaws.

Signalling. A second function of opposition amendments is signalling policy alternatives, again with no serious expectation of changing the bill. Publicity is central to opposition strategy (Uhr 2009), and signalling of other kinds is an acknowledged opposition tactic - for example through the introduction of bills (Brunner 2012), or 'issue politicisation' using agenda-setting power (Seeberg 2013). The true audience for such signals is not government, 
but the media, interest groups, and wider electorate. As one frontbencher told us, amendments of this kind allow you 'to put your stall out', and say 'we completely disagree with what you're saying, this is what we would do'. This may help frame wider debates outside parliament, and develop the opposition's own policy thinking. Some signalling amendments are not even particularly focused on the bill under discussion (though must be presented as such, if not to be ruled out of order). One opposition frontbencher described debate on a bill as an 'opportunity to talk about the wider economic issues, because the bill itself was pretty dull or didn't offer much political capital'.

Political gameplaying. Other amendments are simply mischievous. As Griffith (1974: 38) suggested, '[t] he purpose of many Opposition amendments is not to make the bill more generally acceptable but to make the Government less generally acceptable'. These amendments primarily seek not to advertise the opposition, but to embarrass or split the government, and may take two main forms. Some are substantive, described by interviewees as 'the ideological ones' or 'straight political', being designed to 'hijack the bill and highlight the bill's inadequacies... in no way to improve the bill'. So in one case, 'just to make the government have to say "yeah, we want to cut benefits"، Post-2010, many Labour opposition amendments sought to destabilise the coalition, particularly through forcing the centrist Liberal Democrats to vote for apparently 'right wing' policies. Other amendments instead facilitated procedural complaints, for example allowing opposition frontbenchers to argue that insufficient time for debate had been provided. We were told that at committee stage, 'you've got to be seen using up all those sessions', and 'there are various tricks that you can use to string it out' - including tabling numerous amendments. Likewise opposition frontbenchers 'can't not bring amendments forward at report stage, because then it looks like either the government's doing something right or we're not interested'.

Procedural devices. A fourth opposition tactic is also procedural but more constructive, by using some amendments to manipulate the timing of debates and hence facilitate discussion of others. Parliamentarians want key amendments debated in 'prime time', so that colleagues are present to vote, and the media may hear the arguments. This matters particularly in the Lords, where lighter whipping makes it hard for the opposition to win votes late at night. Hence frontbenchers explained that 'sometimes you would put some [amendments] down to, not exactly to make the sitting longer, but to work out a timetable'. It is thus important to 'have some amendments that you could drop'.

Although strict quantification would be difficult (in part because they are not mutually exclusive) the great majority of opposition frontbench amendments at Westminster almost certainly fall into one of these four categories. Hence if such amendments fail to change the wording in a bill, it would be far too simplistic to interpret this (as many casual observers are prone to do) as a sign of opposition failure. For the opposition frontbench, 'success' may instead come in various other forms.

Given these multiple motivations, and the government's natural hostility to opposition amendments, it is perhaps surprising that so many strands coded 'not unsuccessful' - 139 in total - originated with one of the main opposition parties. Despite scholars' established expectations of Westminster opposition, a final motivation is thus clearly to change the bill, though this admittedly blurs somewhat with other motivations set out above. If probing amendments uncover government vulnerabilities, or signalling attracts significant outside support, more policy-oriented amendments may follow at later stages. In addition some opposition frontbench amendments - particularly in the less confrontational settings of 
Commons committee stage or the Lords - are from the outset constructive attempts to present workable policy alternatives.

Of the 139 'not unsuccessful' opposition-initiated strands, just 20 were resolved wholly within the Commons, and with no involvement by government backbenchers. ${ }^{14}$ The Commons opposition can very rarely win a vote against a majority government (and any surprise committee stage defeats can normally be easily overturned on report). The 20 cases included Conservative committee-stage amendments to remove an exemption for public authorities with a duty of care towards children from the Corporate Manslaughter Bill, and to explicitly include an offence of 'manufacturing' false ID cards in the Identity Cards Bill. ${ }^{15}$ But most opposition frontbench-initiated strands with policy effect involved either the Lords (in 105 cases) and/or related Commons amendments with government backbench support. Since 1999, the opposition has had the potential to inflict defeat on government through the 'no overall control' House of Lords, though many opposition-inspired changes to the bills in the Lords were also achieved through negotiation. Since defeats require cross-party support, and even consensual Lords changes depend to some extent on ministerial concerns about such cross-party alliances forming, we discuss these issues separately below.

\section{Government backbenchers}

In contrast to opposition frontbenchers, just 186 of 2050 strands (9.1\%) were initiated solely by government backbenchers. In terms of success rates, while the proportion of opposition policy initiatives succeeding might seem high from a traditional Westminster perspective, the proportion of backbench-initiated strands leading to policy change ( $24 \%$ across the whole period) demonstrates little sign of the centrality of King's (1976) 'intraparty mode'. However an examination of motivations behind amendments, plus consideration of government's relationship with its backbenchers, again shows a more complex situation. Here our results noted elements of continuity between backbench behaviour under the single-party Labour government pre-2010 and the post-2010 coalition, but also some elements of discontinuity, as noted below.

Government backbenchers share some, but not all, of the motivations ascribed to opposition frontbenchers. 'Information seeking' (probing) amendments are sometimes moved to explore a bill's meaning or the government's intent in its implementation, but most of this work is left to the opposition. Backbenchers also occasionally use procedural devices to facilitate other sincere amendments. In contrast, 'political gameplaying' is unlikely on the government's own side. 'Signalling' is also rare, but not unknown - and became more common under the coalition. Pre-2010 some Labour MPs (particularly established mavericks) used amendments as signalling devices to groups outside parliament - as for example when some backbenchers proposed a new clause to the Employment Bill to reform strike balloting arrangements. This was unrelated to the bill's core topics, and Labour frontbenchers strongly resisted it (with opposition support). But it sent clear signals to left-wing trade unions and activists.

Under coalition, UK scholars have noted the Liberal Democrats' 'serious problem ... [of] signalling to the public their distinctive contribution in [the Conservative-led] government' (Yong 2012: 115). Studies of coalition elsewhere suggest that parliament can provide a forum to signal policy differences between the partners (e.g. Martin and Vanberg 2008, 2011). We found some evidence of this, with interviewees reporting critical LibDem backbench amendments having been unofficially sanctioned by the party's frontbenchers, either to bolster their negotiating strength within the coalition, or to placate party activists. Despite this 
party's far smaller size, its backbenchers notably initiated far more strands ( 84 to 22 ) than Conservatives in this period.

But government backbenchers mostly do not wish to embarrass the government or delay its legislation, so their amendments will more often be serious attempts to alter policy.

Nonetheless not all seek immediate legislative change, and here there are two other important motivations.

Attempts at non-legislative change. Since most government backbenchers broadly support the direction of policy, their amendments often focus on the detail. Demands may thus be satisfied through changes short of amending the bill itself - e.g. by promises from ministers about future policy guidance to public authorities, increased funding, or simply clear statements in Hansard about the bill's legal interpretation (notably, these can have legal force in the British courts ${ }^{16}$ ). Hence ministers' precise wording in response to amendments is occasionally negotiated with backbenchers behind-the-scenes. The same can occasionally apply to the opposition, but backbenchers' demands, being more modest, may be more easily satisfied. They also have less interest in visible 'victory' on the face of the bill.

Markers for the future. Given government backbenchers' general sympathy with the prevailing policy direction, they often play what interviewees described as a 'long game': using debates on a bill to flag future policy priorities. As one backbencher put it 'I wasn't planning to try and seriously get any amendments to the bill', but instead making proposals for 'things I wanted ministers to think about'. Another spoke of private meetings that 'strike some kind of a deal to say, look, what I want is the minister to say warm words about this amendment'. This can feed future policy development, within either the governing party or the executive. Such amendments could be seen as another form of 'signalling', but differ by targeting the government itself, and sincere policy negotiation, rather than broadcasting policy differences to the outside world.

As with opposition frontbenchers, government backbench 'failure' cannot thus be taken at face value, as such parliamentarians may feel they have achieved their goals without changes to the bill. Yet a final motivation for their amendments is, of course, achieving immediate legislative change. And there are obvious reasons why government should take such amendments seriously. As King (1976: 15) put it, 'ministers have needs of Government backbenchers. They need their moral support. They need them not to cause rows and to make hostile speeches that will attract publicity. They need, above all, their votes'. Whips may try to rein in errant backbenchers, but if they propose serious amendments with wide backing, ministers may be forced to think again. One former minister explained that 'you'd be barmy' not to listen to backbenchers on the government side, whereas confronted with opposition objections you can 'just plough on'.

The fact that few changes were driven solely by government backbench amendments doesn't necessarily indicate backbench weakness; indeed, it could be interpreted as the reverse. If the relationship between parliament and government is viewed as one between principal and agent, a lack of conflict may simply signify the agent acting as the principal desires (McGann 2006, Strøm 2000). Ministers and their backbenchers share broadly similar policy objectives, so it is unsurprising if the former often act as the latter want. But where ministers face pressures to introduce controversial measures, and must think through parliament's likely reaction, as one former minister told us, 'your own backbenchers are the ones you worry about the most'. This dynamic is expressed by Blondel's $(1970: 78,82)$ 'preventive' rather 
than 'reactive' legislative power - which has conventionally resided largely with government backbenchers. We thus found examples of policies being amended prior to introduction to satisfy government backbench concerns - a dynamic which may usually result in 'watering down' of government initiatives, but at times can also drive policy introduction. The Corporate Manslaughter and Corporate Homicide Bill had been pressed on government for years by its backbenchers (and trade unions, and the wider party), and was introduced only reluctantly by civil servants and senior ministers. One government insider, explaining why this happened, commented that there is 'constant' pressure from government backbench MPs and 'you have to reach a sort of modus vivendi with them and... have some policy agreement on some issues that they think are important'. Yet such dynamics are largely invisible to the outside world.

In terms of the relatively small numbers of concessions to government backbenchers in parliament, under Labour these included new provisions to 'name and shame' offenders in the Corporate Manslaughter Bill, and to extend provisions in the Saving Gateway Accounts Bill to recipients of carers' benefit. More such concessions were given under coalition, primarily in response to backbench Liberal Democrats. But we found little evidence of an 'interparty' parliamentary mode, with the junior coalition partner using parliament to 'police the bargain' as other studies have suggested (Martin and Vanberg 2004, 2011). In the 2010 coalition all departments included ministers from both parties which, alongside a complex range of inter-party bodies inside the executive, primarily fulfilled this purpose instead. Hence changes responding directly to backbench Liberal Democrats amendments - like those under Labour - tended to be small. ${ }^{17}$ Larger changes, in contrast, involved elements of crossparty working, as we discuss next.

\section{Cross-party and non-party working}

King (1976) suggested that cross-party working was weak to non-existent at Westminster. But since then much has changed - in terms of declining party cohesion, and establishment of specialist committees, followed by the 'no overall control' House of Lords. In the latter forum from 1999 to 2010 the two main opposition parties jointly could fairly readily defeat the Labour government, while post-2010 Labour could defeat the Conservative-LibDem coalition if supported by sufficient independent 'Crossbenchers'. Such defeats have become fairly commonplace, often resulting in government climbdowns (Russell 2013, Russell and Sciara 2008).

In both chambers, government backbenchers cannot inflict defeats unless their amendments can gain opposition support, while even in the Lords opposition frontbenchers know that they will struggle ultimately to succeed if government backbench opinion is solid, since hostile amendments can be overturned in the Commons. ${ }^{18}$ Thus growing incentives exist for crossparty working. The select committees, which are increasingly respected for their expert status and nonpartisan cross-party ethos, add to this. They have no formal role in amending legislation (the committee stage instead occurring on the floor of the chamber or in a Commons 'public bill committee'). But some Lords and joint committees routinely report on bills from a constitutional perspective, while Commons departmental select committees also occasionally comment.

In terms of visible influence through amendments, cross-party collaboration on changes to bills in our sample took two forms - largely mirroring these two opportunities. First, informal 
coalitions of support around particular proposals, and second, formal interventions from select committees. We deal with informal coalitions first.

Up to this point, we have considered party groups proposing amendments largely as separate: opposition frontbench or government backbench. But Table 2 indicated that cross-party support is also fairly common. This can involve joint working between two opposition parties, an opposition party and government backbenchers, or the inclusion of others. In the Commons these are limited to small numbers of MPs from Northern Ireland parties, and nationalists in Scotland and Wales; in the Lords they mostly comprise the (very numerous) Crossbenchers. Table 2 shows that 133 legislative strands in 2005-10 began with amendments sponsored on a cross-party basis (broadly defined, to include non-party parliamentarians). A marginally higher proportion of these $(14.3 \%)$ resulted in change than amendments initiated by any single non-government group. In 2010-12 the number of such initiatives remained stable (mostly comprising Labour/Crossbench partnerships in the Lords), and at $33.6 \%$ their success rate substantially exceeded that of the opposition.

But Table 2 reflects only the proposers of the initial amendment(s) in each legislative strand, and cross-party cooperation goes far further. In terms of measurable support demonstrated through amendments, other actors may sign related amendments later in a strand, or in a very similar 'sibling' strand. ${ }^{19}$ Including these indicators within the definition, $25 \%$ of nongovernment-initiated strands in $2005-10$ and $27 \%$ in $2010-12$ could be considered crossparty. ${ }^{20}$ Cross-party initiatives were markedly more common among Lords-only strands (25\% over the whole period) than Commons-only strands (12\%), but were most common among strands pursued across both chambers ( $50 \%$, or 191 of 385$)$. These latter cases were the ones where the government came under the most sustained pressure, both cross-party and intercamerally. Crucially, policy change was far more likely to result from strands demonstrating cross-party support (as just defined): $20 \%$ of such strands were coded 'not unsuccessful' in 2005-10, compared to 7\% of those with only single party support; in 201012 the equivalent figures were $33 \%$ and $20 \%$ (in both cases, chi-squared $\mathrm{p}<0.001$ ). Beyond signing up to amendments, other forms of cross-party collaboration (not reflected in these figures) will increase the pressure: including behind-the-scenes conversations, speeches in debate, and crucially - should an amendment be pushed to that point - votes in the division lobbies.

These statistics give little feel for how informal cross-party coalitions at Westminster tend to come about. They may begin with a joint-sponsored amendment, but more often in an uncoordinated way, through similar amendments proposed by more than one group at committee stage. If these uncover government weaknesses groups may join forces, with more determined attempts at report stage or (for the majority of bills that begin in the Commons) on arrival in the Lords. If there is a real desire for policy change, initial proponents actively seek out new supporters. Lords interviewees particularly emphasised how cross-party working was a key means for getting ministers to listen. One Conservative frontbencher, reflecting on Labour's time in government, said that 'the real trick was to have four names: one Conservative, one Liberal Democrat, one Crossbench and one Labour'. Indeed one opposition frontbencher in the Lords commented that when proposing amendments 'it's partly a signal to the government that you're not serious if you do it [only] in your own name'.

Returning to motivations, explicit, organised cross-party initiatives fit relatively easily into the categories above. Coordination on probing or political gameplaying is unusual, while 
procedural devices are in any case fairly rare. This leaves signalling, and genuine attempts at (legislative or nonlegislative) policy change. During 2005-10, joint signalling by the two opposition parties occurred frequently, as a means of making the Labour government appear isolated - as for example when Conservative and Liberal Democrat frontbenchers worked together to demonstrate their libertarian credentials in opposing the Identity Cards Bill. Likewise, Labour made considerable efforts post-2010 to enlist respected Crossbench 'experts', for example in attacking the coalition's so-called 'bedroom tax' in the Welfare Reform Bill. But generally, given the makeup of the Lords, such initiatives were partly genuine attempts at policy change.

The biggest policy reversals on the case study bills tended to occur on amendments demonstrating broad cross-party support. For example, a proposal to extend the new corporate manslaughter law to deaths in (police, etc) custody began with the Labour chairs of two select committees in the Commons. It was then pursued by a joint opposition alliance in the Lords, headed by Crossbench expert David Ramsbotham. Similarly a Conservative/Liberal Democrat initiative to remove compulsion from the identity cards scheme capitalised on disquiet among Labour backbenchers, in part because the party's manifesto had promised a voluntary scheme. Both initiatives triggered government reversals.

But cross-party working is not merely a matter of informal coalitions, and it is certainly not limited to the Lords. Among our case studies, 47 strands included government amendments traceable to select committee recommendations. In 13 cases ministers simply responded voluntarily to the committee. But the remainder involved at least one non-government amendment pressing the case, and some of these were substantial. For example several committees proposed major changes to the Public Bodies Bill, which were pursued through non-government amendments with cross-party support. These included initiatives led by Conservative peer Lord Norton (a former Constitution Committee chair) to delete a schedule of 150 bodies identified for abolition, and by Liberal Democrat Lord Lester (a Joint Committee on Human Rights member) to protect judicial bodies. The latter committee also helped start the chain of amendments on deaths in custody in the Corporate Manslaughter Bill. Another major change concerned the ban on smoking in public places in Labour's Health Bill 2005-06 - where the government had originally proposed certain exclusions, but a critical report from the Commons Health Committee instead called for a comprehensive ban. Committee members lobbied for this, and it was agreed overwhelmingly by MPs after the government conceded an unwhipped vote.

While King's (1976) 'opposition mode' may therefore not result in much policy change - and indeed should not be expected to - opposition politicians now contribute jointly with government backbenchers to a far more effective 'cross-party mode' than he identified. Development of specialist committees, and latterly Lords reform, have boosted this increasingly visible influence. But its greatest effect - like that of backbenchers - probably comes through 'anticipated reactions', shaping proposals before they are put to parliament. Benton and Russell (2012: 792) have emphasised how anticipated reactions are key to select committee power, with ministers often asking themselves 'how would this look if there was an inquiry into it?'. Ministers will likewise work hard to avoid informal cross-party coalitions forming, and causing problems in the Lords. As Russell $(2010,2013)$ documents, since the late 1990s government departments have been required to prepare written parliamentary 'handling strategies', for cabinet committee approval before any bill is introduced. These must identify any parliamentary pressure points and how they will be dealt with (see for example Cabinet Office 2012). While handling strategies initially focused only on the Lords, 
they now extend to the Commons, not least because cross-party alliances formed there may spread to the other chamber. In this respect backbenchers in the Commons remain, as King (1976) highlighted, crucially important. But ministers must now also work hard to consider the reaction of other parliamentarians, in both chambers.

\section{Conclusions}

This article reports on the largest study of Westminster's legislative process for 40 years, which to our knowledge is the largest detailed amendment analysis to date in any domestic parliament. By studying 4361 amendments proposed to 12 government case study bills, complemented by over 120 interviews, we have explored which actors have legislative influence at Westminster. But our analysis has also highlighted the complexity of such a question, in any parliament. First, visible influence through successful amendments (even when defined widely, to include government concessions in response) tells only a partial story. This captures Blondel's (1970) 'reactive' influence, meaning how parliament responds to proposals made to it by government; but parliament's 'preventive' influence, in determining what government brings forward in the first place, is at least as important. Second, when considering the degree of 'success' of non-government legislative amendments it must be recognised that these serve many purposes, not all being motivated by changing the bill at hand.

In terms of influential actors at Westminster, our construction of legislative 'strands', linking all related amendments on a topic (including government concessions) detected both opposition and government backbench influence on bills. Numerically, more oppositioninitiated strands 'succeed', but the success rate of government backbenchers is if anything marginally higher. Nonetheless the importance of this latter group is not readily visible through amendment success, as King's (1976) 'intraparty mode' operates largely behind the scenes, including before bills are introduced. His interparty mode, between coalition partners, has appeared at Westminster since 2010 - but is likewise largely played out privately, rather than in the glare of parliamentary publicity.

The most striking departure from King's characterisation of Westminster, however, is the growth of a 'cross-party mode' - which he considered essentially non-existent. Nongovernment strands demonstrating cross-party support proved particularly likely to result in policy change (primarily through government concessions). Lords reform in 1999, the growth of select committees, and declining party cohesion, have all fed the ability for nongovernment actors to work together across party lines. And while this success is traceable through legislative change, its bigger impact is again almost certainly 'preventive'. UK Ministers must now be responsive to a wide range of parliamentary actors to avoid the formation of blocking coalitions.

Our findings thus have importance for British politics, suggesting influence at Westminster to be significantly more plural than traditionally thought. Britain appears to be moving from its long-held position as the key exemplar of a majoritarian, executive-dominated parliament to something closer to Lijphart's (2012) consensus model. Nonetheless parliaments serve many functions, and our findings - particularly our interview data - point to the many purposes of non-government legislative amendments. The Westminster opposition is classically not seen as policy-seeking, and we demonstrate how other political objectives may play out through the amendment process - identifying four opposition motivations behind amendments other than seeking to change the bill. Government backbenchers likewise have additional such 
motivations, which are more policy-focused but likewise not always targeted at immediate change.

Table 3 summarises the eight distinct motivations that we identified, and their mapping onto different groups. Government amendments at Westminster are invariably sincere, though many are minor and technical. Opposition amendments may be information seeking, signalling, gameplaying or simply procedural. Government backbench amendments are more often aimed at (or at least satisfied by) modest non-legislative changes, or at influencing future policy rather than the present bill. In contrast, when non-government parliamentarians sincerely wish to pursue legislative change, they routinely work cross-party.

Table 3: Motivations for amendments, by type of policy actor

\begin{tabular}{|l|c|c|c|c|}
\hline & Government & Opposition & $\begin{array}{c}\text { Government } \\
\text { backbench }\end{array}$ & $\begin{array}{c}\text { Cross-party } \\
\text { coalitions* }\end{array}$ \\
\hline 1. Legislative change & $\checkmark$ & $\checkmark$ & $\checkmark$ & $\checkmark$ \\
\hline 2. Non-legislative change & $\mathrm{X}$ & $\sim$ & $\checkmark$ & $\sim$ \\
\hline 3. Information seeking & $\mathrm{X}$ & $\checkmark$ & $\sim$ & $\mathrm{X}$ \\
\hline 4. Signalling & $\mathrm{X}$ & $\checkmark$ & $\sim$ & $\sim$ \\
\hline 5. Gameplaying & $\mathrm{X}$ & $\checkmark$ & $\mathrm{X}$ & $\mathrm{X}$ \\
\hline 6. Procedural & $\mathrm{X}$ & $\sim$ & $\sim$ & $\sim$ \\
\hline 7. Future policy & $\mathrm{X}$ & $\mathrm{X}$ & $\checkmark$ & $\mathrm{X}$ \\
\hline 8. Technical amendments & $\checkmark$ & $\mathrm{X}$ & $\mathrm{X}$ & $\mathrm{X}$ \\
\hline
\end{tabular}

Key: $\checkmark=$ used frequently; $\sim$ used occasionally; $X=$ not used.

*This is interpreted more broadly than the two previous columns combined, including joint working between the two main opposition parties under Labour.

These categories may well not have universal application. They are necessarily influenced both by Westminster's established patterns of party competition and its specific procedural rules. While the former may be edging closer to the European norm, the latter still potentially creates context-specific incentives for amendments. For example Westminster's emphasis on 'probing' amendments may not be matched in other settings. Researchers working on other systems may well thus be able to expand on our typology. But it provides an initial starting point.

This paper has urged greater clarity about the multiple motivations behind non-government legislative amendments. As indicated at the start, scholars often suggest that the great majority of non-government initiatives in parliament 'fail', while executive initiatives dominate. But both conclusions may be exaggerated. Executives can be more responsive than commonly assumed, both through concessions to non-government initiatives - as we have traced, and to 'preventive' influence behind the scenes. But crucially, judging nongovernment 'failure' on the basis that amendments do not reach the statute book risks misunderstanding key parliamentary dynamics. If parliamentarians have multiple motivations for proposing legislative amendments, such proposals may be far more 'successful' at achieving their goals than is commonly assumed. 
${ }^{1}$ This work was funded by the Nuffield Foundation, and draws on earlier work funded by the ESRC under grant RES-063-27-0163. We are grateful to the anonymous reviewers for their comments.

${ }^{2}$ The complete set of bills (and session/s in which they received formal parliamentary scrutiny) were the Identity Cards Bill (2005-06), Health Bill (2005-06), Corporate Manslaughter and Corporate Homicide Bill (2005-07), Further Education and Training Bill (2006-07), Employment Bill (2007-08), Saving Gateway Accounts Bill (2008-09), Energy Bill (2009-10), Identity Documents Bill (2010-12), Budget Responsibility and National Audit Bill (2010-12), Saving Accounts and Health in Pregnancy Grant Bill (2010-12), Public Bodies Bill (2010-12) and Welfare Reform Bill (2010-12).

${ }^{3}$ Complete options for those not decided either way were: not called (776) or not selected (227) - both of which apply only in the Commons where the Speaker has this power; not moved (1111); withdrawn (931); withdrawn prior to debate (217).

${ }^{4}$ Here 'actor' can refer to a single parliamentarian, or a group working together (e.g. several co-sponsors of a package of amendments). In a small number of cases amendments by overlapping groups of actors at the same stage were stranded together.

${ }^{5}$ Sometimes government amendments resolved multiple earlier non-government amendments in separate strands about the same broad issue. We generally assigned government amendments to the strand with the most similar prior amendments. But it would be misleading to ascribe success only to one actor in such cases, and to consider the other strands as unsuccessful. To avoid double counting government concessions we coded one strand as 'successful' and any others as 'neither successful nor unsuccessful'.

${ }^{6}$ [Reference withheld] explains that there are various reasons for this dynamic: the wish to deny the opposition a clear victory, the need to take time consulting inside government before changing policies, and the desire to ensure that legislative drafting is technically correct.

${ }^{7}$ In a handful of cases where amendments were jointly sponsored by a minister and non-government parliamentarian(s), we classify them - as do the Westminster authorities - as government amendments.

${ }^{8}$ Four in the House of Commons, and 121 in the Lords.

${ }^{9}$ Non-substantive amendments were those which were technical, consequential or clarificatory. Responding to non-government parliamentarians included to earlier non-government amendments, committee recommendations, or (in a few cases) points raised in earlier debates.

${ }^{10}$ We use the definition 'not unsuccessful' here, to avoid ascribing influence unfairly: see note 5 .

${ }^{11}$ On the coalition's Public Bodies Bill the government responded to a raft of non-government Lords amendments protesting against individual bodies identified for possible abolition by agreeing to delete an entire schedule listing 150 such bodies. This resolved 70 separate non-government strands.

${ }^{12} 1116$ amendments were in the Commons, and 912 in the Lords. Opposition defined as Conservative or Liberal Democrat 2005-10, Labour 2010-12. Minor parties move relatively few amendments, which are excluded.

Figures in this section exclude amendments sponsored jointly by opposition frontbench parties, or between them and other groups, which are included below under 'cross-party working'.

${ }^{13}$ In the Lords there is no selection of amendments.

${ }^{14}$ Amendments by different actors at the same stage seeking essentially identical changes were placed in separate strands coded as 'siblings'. Stranding such amendments together proved impractical, as in some cases different actors modified their demands stage-by-stage, and the effects of their amendments diverged. When defining government backbencher involvement, we include involvement in siblings strands.

${ }^{15}$ Some were on more minor matters, such as subjecting subsequent regulations under a bill to the 'affirmative' rather than 'negative' parliamentary procedure.

${ }^{16}$ Following the Pepper vs. Hart decision of 1993.

${ }^{17}$ See note 15 .

${ }^{18}$ Russell's (2013) statistical analysis finds government to be more responsive to Lords defeats when opponents include rebels on the government side. Such dynamics are sometimes overlooked by scholars - for example Martin and Vanberg (2005) suggest that oppositions in 'consensus' democracies are less influential than commonly assumed, because it is ideological difference within the coalition that matters. The truth is of course that both are necessary if the opposition is to build a majority against the government.

${ }^{19}$ See note 14 .

${ }^{20} 261$ of 1059 and 220 of 805 respectively. 


\section{Bibliography}

Andeweg, R. B. (2013), 'Parties in Parliament: The Blurring of Opposition' in W. C. Müller $\&$ H. M. Narud, eds, Party Governance and Party Democracy (New York: Springer).

Arter, D. (1985), 'The Nordic Parliaments: Patterns of Legislative Influence', West European Politics, 8(1), 55-70.

Benton, M. and Russell, M. (2012), 'Assessing the Impact of Parliamentary Oversight Committees: The Select Committees in the British House of Commons', Parliamentary Affairs, 66(4), 772-97.

Blondel, J. (1970), 'Legislative Behaviour: Some Steps Towards a Cross-National Measurement', Government and Opposition, 5(1), 67-85.

Brunner, M. (2012), Parliaments and Legislative Activity: Motivations for Bill Introduction (Wiesbaden: Springer VS).

Cabinet Office (2012), Guide to Making Legislation (June 2012 edn.) (London: The Stationery Office).

Cowley, P. (2002), Revolts and Rebellions: Parliamentary Voting Under Blair (London: Politico's).

Cowley, P. (2005), The Rebels: How Blair Mislaid His Majority (London: Politico's).

Cowley, P. and Stuart, M. (2012), The Bumper Book of Coalition Rebellions (Nottingham: University of Nottingham).

Flinders, M. and Kelso, A. (2011), 'Mind the Gap: Political Analysis, Public Expectations and the Parliamentary Decline Thesis', British Journal of Politics and International Relations, 13(2), 249-68.

Griffith, J. A. G. (1974), Parliamentary Scrutiny of Government Bills (London: Allen and Unwin).

Helms, L. (2004), 'Five Ways of Institutionalizing Political Opposition: Lessons from the Advanced Democracies', Government and Opposition, 39(1), 22-54.

Helms, L. (2008), 'Studying Parliamentary Opposition in Old and New Democracies: Issues and Perspectives', The Journal of Legislative Studies, 14(1-2), 6-19.

Johnson, N. (1997), 'Opposition in the British Political System', Government and Opposition, 32(4), 487-510.

Judge, D. and Earnshaw, D. (2003), The European Parliament (Basingstoke: Palgrave).

Kaiser, A. (2008), 'Parliamentary Opposition in Westminster Democracies: Britain, Canada, Australia and New Zealand', Journal of Legislative Studies, 14(1), 20 - 45.

Kelso, A. (2009), Parliamentary Reform at Westminster (Manchester: Manchester University Press).

Kerrouche, E. (2006), 'The French Assemblée Nationale: The Case of a Weak Legislature?', Journal of Legislative Studies, 12(3), 336-65.

King, A. (1976), 'Modes of Executive-Legislative Relations: Great Britain, France and West Germany', Legislative Studies Quarterly, 1(1), 11-36.

Kinnock, N. (2011), 'Leading the Opposition' in N. Fletcher, ed, How to be in Opposition: Life in the Political Shadows (London: Biteback).

Kreppel, A. (1999), 'What Affects the European Parliament's Legislative Influence? An Analysis of the Success of EP Amendments', Journal of Common Market Studies 37(3), 521-37.

Kreppel, A. (2014), 'Typologies and Classifications' in S. Martin, T. Saalfeld \& K. Strom, eds, The Oxford Handbook of Legislative Studies (Oxford: Oxford University Press).

Lijphart, A. (2012), Patterns of Democracy: Government Forms and Performance in ThirtySix Countries (New Haven: Yale University Press). 
Martin, L. W. and Vanberg, G. (2004), 'Policing the Bargain: Coalition Government and Parliamentary Scrutiny', American Journal of Political Science, 48(1), 13-27.

Martin, L. W. and Vanberg, G. (2005), 'Coalition Policymaking and Legislative Review', American Political Science Review, 99(1), 93-106.

Martin, L. W. and Vanberg, G. (2008), 'Coalition Government and Political Communication', Political Research Quarterly, 61(3), 502-16.

Martin, L. W. and Vanberg, G. (2011), Parliaments and Coalitions: The Role of Legislative Institutions in Multiparty Governance (Oxford: Oxford University Press).

McGann, A. (2006), 'Social Choice and Comparing Legislatures: Constitutional versus Institutional Constraints', Journal of Legislative Studies, 12(4), 443-61.

Mezey, M. L. (1979), Comparative Legislatures (Durham, NC: Duke University Press).

Norton, P. (2008), 'Making Sense of Opposition', The Journal of Legislative Studies, 14(1-2), 236-50.

Russell, M. (2010), 'A Stronger Second Chamber? Assessing the Impact of House of Lords Reform in 1999, and the Lessons for Bicameralism', Political Studies, 58(5), 866-85.

Russell, M. (2013), The Contemporary House of Lords: Westminster Bicameralism Revived (Oxford: Oxford University Press).

Russell, M. and Sciara, M. (2008), 'The Policy Impact of Defeats in the House of Lords', British Journal of Politics and International Relations, 10(4), 571-89.

Ryle, M. (2005), 'Forty Years on and a Future Agenda' in P. Giddings, ed, The Future of Parliament: Issues for a New Century (Basingstoke: Palgrave).

Seeberg, H. B. (2013), 'The Opposition's Policy Influence through Issue Politicisation', Journal of Public Policy, 33(1), 89-107.

Shephard, M. and Cairney, P. (2005), 'The Impact of the Scottish Parliament in Amending Executive Legislation', Political Studies, 53(2), 303-19.

Strøm, K. (2000), 'Delegation and Accountability in Parliamentary Democracies', European Journal of Political Research, 37(3), 261-89.

Thompson, L. (2013), 'More of the Same or a Period of Change? The Impact of Bill Committees in the Twenty-First Century House of Commons', Parliamentary Affairs, 66(3), 459-79.

Uhr, J. (2009), 'Parliamentary Opposition Leadership' in H. Patapan, P. 'T Hart \& J. Kane, eds, Dispersed Democratic Leasership (Oxford: Oxford University Press).

Yong, B. (2012), 'The Coalition in Parliament' in R. Hazell \& B. Yong, eds, The Politics of Coalition: How the Conservative-Liberal Democrat Government Works (Oxford: Hart).

Zubek, R. (2011), 'Negative Agenda Control and Executive-Legislative Relations in East Central Europe, 1997-2008', Journal of Legislative Studies, 17(2), 172-92. 